\title{
EFFECTS OF CALCIUM HYDROGEN PHOSPHATE ON LEAD UPTAKE BY COWPEA
} (VIGNA UNGUICULATA)

${ }^{1}$ Dagari, M. S. and ${ }^{2}$ Musa, M. S.*

${ }^{1}$ Department of Chemistry, Federal University, Gashua, Nigeria

${ }^{2}$ Department of Pure and Industrial Chemistry, Faculty of Physical Sciences, College of Natural and Pharmaceutical Sciences, Bayero University, Kano, Nigeria

*Corresponding Author's Email: m_smusa@yahoo.com, msmusa.chm@buk.edu.ng, +2348060899099

\begin{abstract}
The effects of calcium hydrogen phosphate on lead $(\mathrm{Pb})$ uptake by cowpea (Vigna unguiculata) were investigated in a growth chamber experiment coupled with atomic absorption spectrophotometry (AAS) and colorimetry analyses. Cowpea seeds were planted and harvested in soil samples treated with $\mathrm{Pb}^{+2}$ added as lead nitrate at the rates of 0,1000 and $3000 \mathrm{mg} / \mathrm{kg}$ followed by calcium hydrogen phosphate $\left(\mathrm{CaHPO}_{4}\right)$ at 0 , 10,50 and $250 \mathrm{mg} / \mathrm{kg}$. Increases in shoot yield brought about by phosphate fertilization were observed to oppress the shoot lead concentration as a result of growth dilution, where the actual amount of lead in shoots was unaffected by phosphate treatment. This work revealed that there is no substantial effect on lead uptake by cowpea, as a result of phosphate fertilization. Therefore, phosphate fertilization is a good means of cowpea production with minimal lead uptake and hence safe for human consumption.
\end{abstract}

Keywords: Cowpea, growth chamber, calcium hydrogen phosphate, fertilization, lead.

\section{INTRODUCTION}

Soil factors controlling lead availability to plants have been well documented. The elevation of $\mathrm{pH}$ promotes the formation of $\mathrm{Pb}$ precipitates as hydroxides, phosphates and carbonates, as well as insoluble complexes with organic matter. Organic material associated with the elevation of $\mathrm{pH}$ slows the absorption of $\mathrm{Pb}$ by plants, as the $\mathrm{Pb}^{2+}$ ion forms complexes with humic compounds of the soil and becomes less available (Kabata-Pendias and Pendias, 2001). Lead still has low mobility in soil due to its different interactions with the environment (Wuana and Okieimen, 2011).

Though, the widespread use of $\mathrm{Pb}$ has discontinued in many countries of the world, it is still used in many industries like car repair, battery manufacturing and recycling, refining, smelting, etc. The visual general symptoms of lead toxicity are fast inhibition of root growth, underdeveloped growth of the plant, blackening of root system and chlorosis. Lead inhibits photosynthesis, let downs mineral nutrition, water balance and enzyme activities (Sharma and Dubey, 2005). These disorders upset normal physiological activities of the plant. At high concentrations, lead may finally result to cell death (Seregin and Ivanov, 2001).

Similarly, lead inhibits germination of seeds and retards growth of seedlings, decreases germination percent, germination index, root/shoot length, tolerance index and dry mass of roots and shoots (Mishra et al., 2006). This work is precisely aimed at investigating the influence of phosphate addition to plant, with respect to lead uptake and disorders in physiological activities of the plant caused by the presence of lead.

\section{MATERIALS AND METHODS}

All reagents, lead nitrate and calcium hydrogen phosphate supplied by Merck (Darmstadt, Germany), nitric acid obtained from Thornton and Ross (Huddersfield, England) used in this study were of analytical grade purity and used without further purification. Deionized water was prepared using a Milli-DI water purification system (Molsheim, France). Glassware and plastic containers were washed with detergent, rinsed with distilled water, soaked in $10 \% \mathrm{HNO}_{3}$ for $24 \mathrm{hr}$ and finally dried in an oven at $80^{\circ} \mathrm{C}$ for $24 \mathrm{hr}$.

\section{Sampling}

Both soil and cowpea seed (Vigna unguiculata) samples used for this study were collected from International Institute of Tropical Agriculture (IITA) farm in Wasai village, Minjibir Local Government Area of Kano State (Figures 1). 


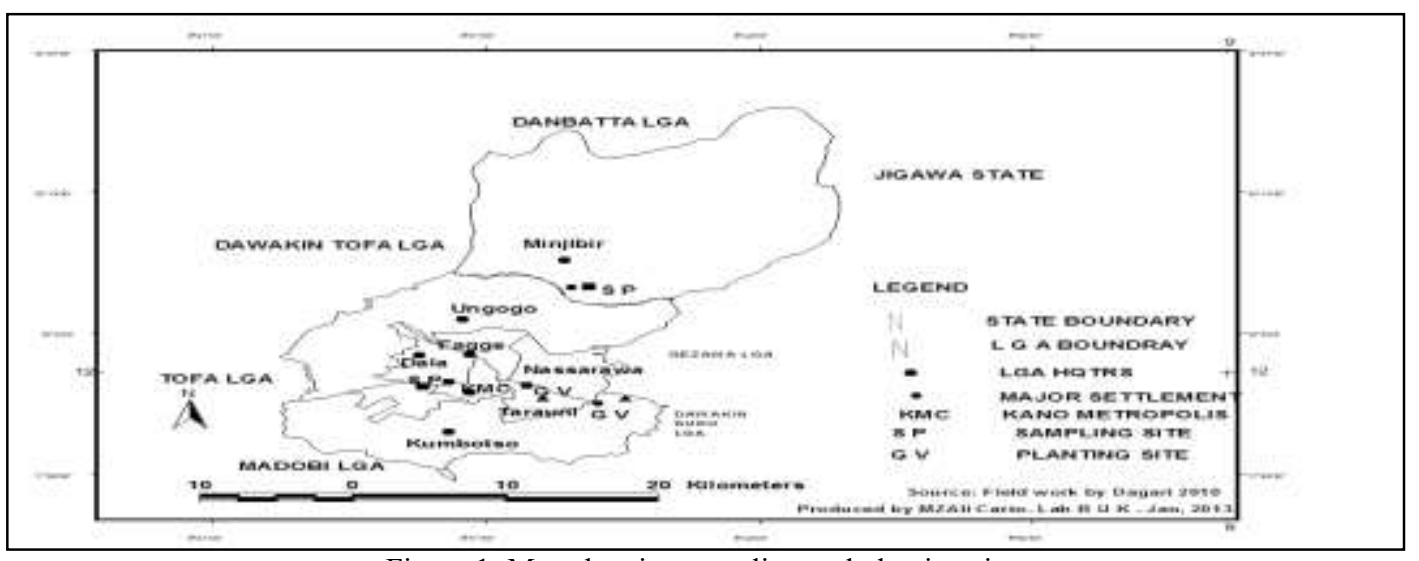

Figure 1: Map showing sampling and planting sites

\section{Plant Preparation}

A growth chamber which regulates the temperature at $26 \pm 2{ }^{\circ} \mathrm{C}$ during a daily 14-hr photoperiod and at $18 \pm 2{ }^{\circ} \mathrm{C}$ during darkness was used to provide uniform atmospheric and climatic conditions for the plant growth. In the factorial experiment with 3 rates of soil $\mathrm{Pb}^{+2}$ treatment $(0,1000,3000 \mathrm{mg} / \mathrm{kg}$ applied as lead nitrate, $\mathrm{Pb}\left(\mathrm{NO}_{3}\right)_{2}$ and 4 rates of calcium hydrogen phosphate $(0,10,50,250 \mathrm{mg} / \mathrm{kg})$ arranged in randomized blocks with 4 replications, plants were grown in 4 litre plastic pots each containing $3 \mathrm{~kg}$ oven dried soil.

The plants were allowed to grow for twelve weeks under glasshouse conditions before taking the first of two shoo harvests, shoots being cut about $3 \mathrm{~cm}$ above the soil surface and dried in paper bags at $80^{\circ} \mathrm{C}$ for $48 \mathrm{hr}$. The second shoot harvest was taken seven weeks later.

\section{Dry Weights of Shoots and Roots}

The dry weights of both shoots and roots were carried out by collecting the harvested portions into dried polyethylene bags and stored in a dark cupboard until constant weights were obtained.

\section{Digestion of samples}

The samples were washed with tap water to remove soil particles, then with $1 \%$ nitric acid for $30 \mathrm{sec}$ to remove lead and phosphate adhered to the outside surfaces. Finally, samples were rinsed with deionised water and allowed to dry in an oven at $80^{\circ} \mathrm{C}$ for $48 \mathrm{hr}$ (Wong and Lau, 1985).

\section{Statistical Tool}

Collection, processing and statistical analysis of the data followed the computer methods described previously by SAS (2002). All data were statistically treated and significance test was performed at $95 \%$ confidence level.

\section{Instrumentation}

All determinations were carried out in three (3) replicates using Agilent Atomic Absorption Spectrophotometer (AAS) for lead and an auto-analyzer (colorimeter) for phosphate. The phosphate was analysed according to the stannous chloride method (Allen, 1989).

\section{RESULTS AND DISCUSSION}

As previously determined, the soil had $1.16 \%$ oxidizable organic matter, 3.44 millieqv/100g of cation exchange capacity, 4.37 exchangeable sodium percentage, $0.02 \mathrm{mS} / \mathrm{cm}$ electrical conductivity, $2.60 \mu \mathrm{g} / \mathrm{g}$ water soluble phosphate and $\mathrm{pH} 7.08$ (Dagari et al., 2020).

\section{Dry Weights of Shoots and Roots}

The variations of dry weights of shoots and roots with added weights of calcium hydrogen phosphate are shown in Figures 2 to

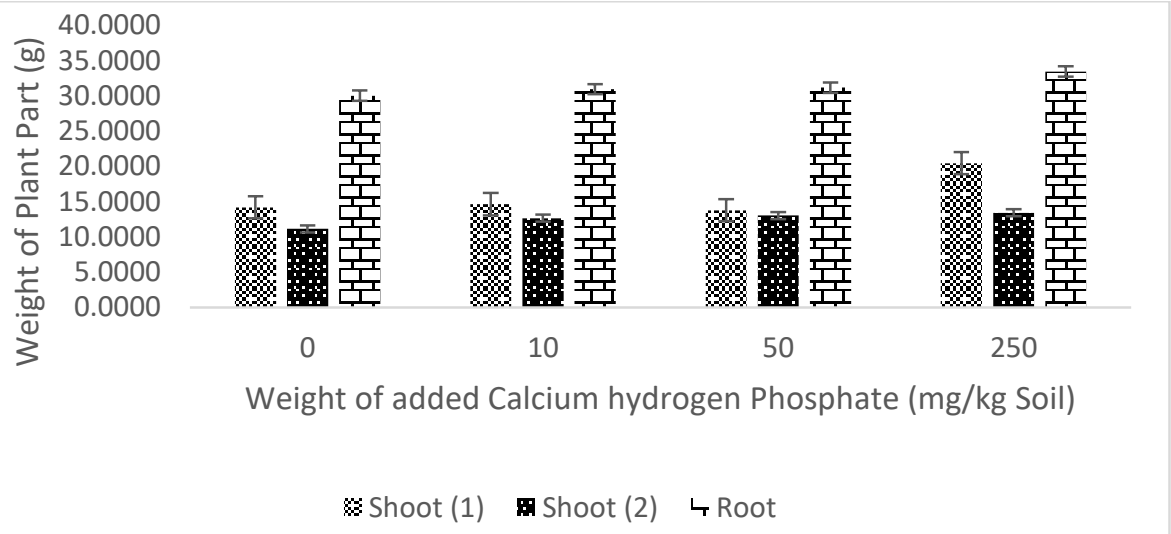

Figure 2: Variations in weights of plant parts against weight of added calcium hydrogen phosphate at $0.0 \mathrm{mg} \mathrm{Pb}$ 


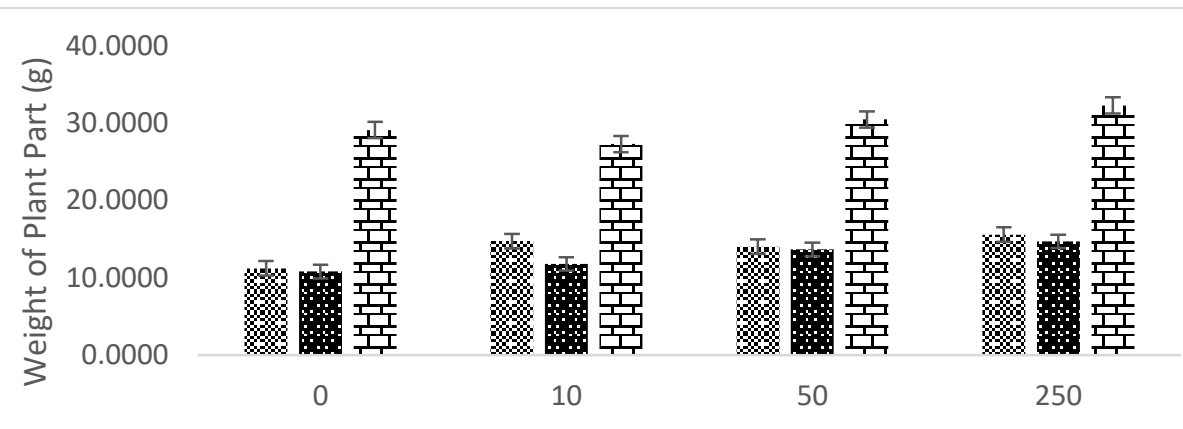

Weight of added Calcium hydrogen Phosphate $(\mathrm{mg} / \mathrm{kg}$ Soil)

Whoot (1) $\mathbf{A}$ Shoot (2) 도 Root

Figure 3: Variations in weights of plant parts against weight of added calcium hydrogen phosphate at $1000 \mathrm{mg} \mathrm{Pb}$

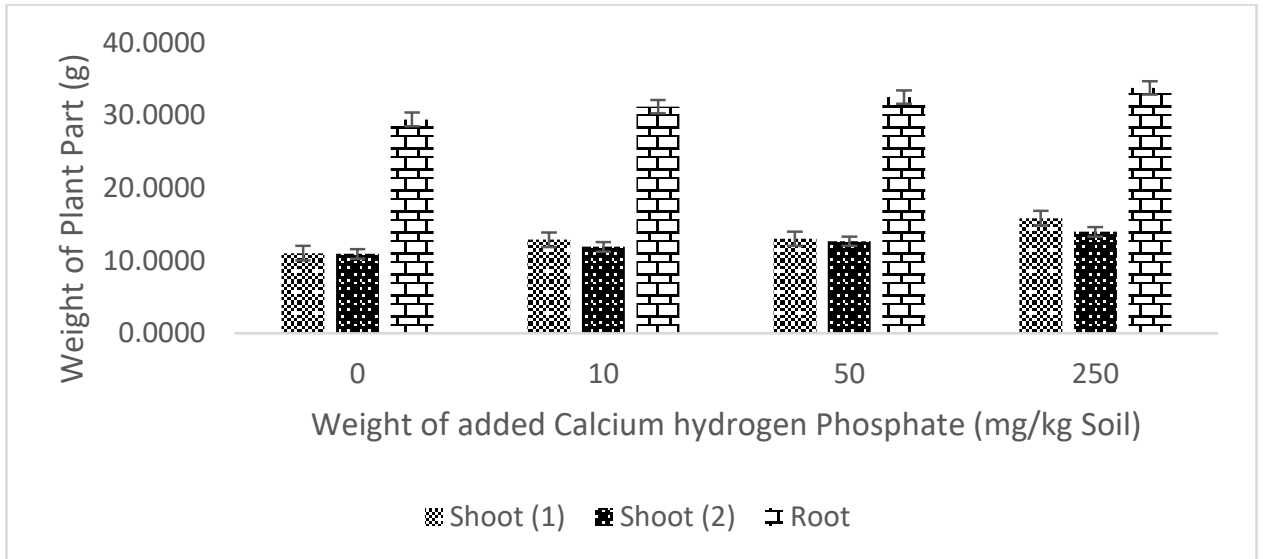

Figure 4: Variations in weights of plant parts against weight of added calcium hydrogen phosphate at $3000 \mathrm{mg} \mathrm{Pb}^{+2}$

Figures 2, 3 and 4 show changes in dry weights of shoots and roots with added weights of calcium hydrogen phosphate were insignificant $(\mathrm{P}>0.05)$. The dry weights ranged from $11.0353 \pm 0.3405$ to $16.1208 \pm 2.9486 \mathrm{mg} / \mathrm{kg}$ for first shoot harvest, $10.8052 \pm 0.6701$ to $14.6984 \pm 0.5751 \mathrm{mg} / \mathrm{kg}$ for second shoot harvest and $27.3279 \pm 1.5730$ to $33.7873 \pm 0.0832$ for roots. In all instances, $10 \mathrm{mg} / \mathrm{kg}$ of calcium hydrogen phosphate was sufficient to bring about the increase in yield.

The first and second shoot yields increased from
$11.2146 \pm 0.4778$ to $14.7366 \pm 4.1556$ and $10.8052 \pm 0.6701$ to $11.7856 \pm 0.7554 \mathrm{mg} / \mathrm{kg}$ for soil amended with $1000 \mathrm{mg} / \mathrm{kg} \mathrm{Pb}^{+2}$ and $10 \mathrm{mg} / \mathrm{kg}$ calcium hydrogen phosphate (Figure 3 ).

Lead Concentration in Shoots and Roots

Addition of lead to soil significantly increased shoot lead concentrations in both harvests and root lead concentrations $(\mathrm{P}<0.05)$ as shown in Figures 5 to 7. 


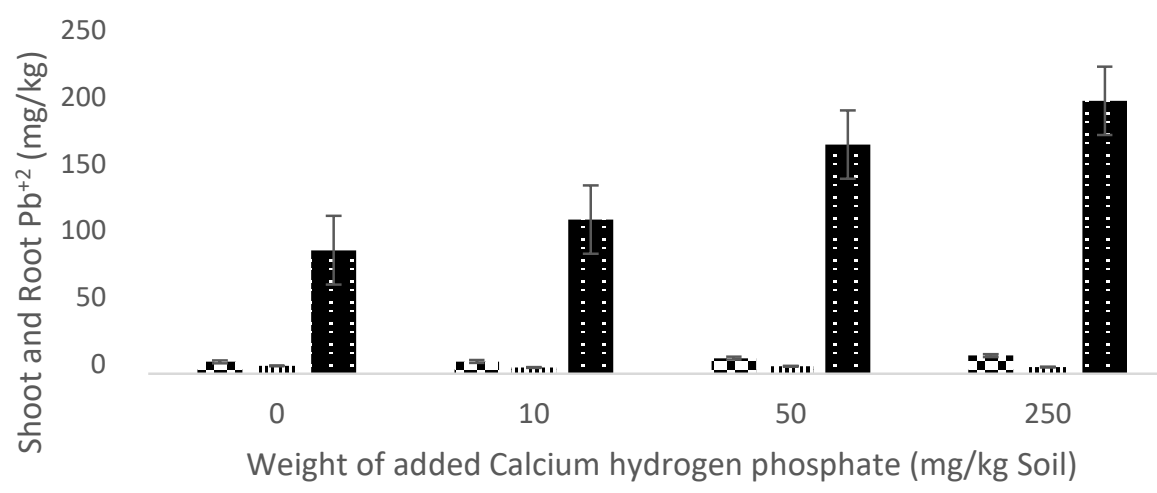

XShoot (1) IIII Shoot (2) Root

Figure 5: Changes in shoot and root lead concentrations against weight of added calcium hydrogen phosphate at $0 \mathrm{mg} \mathrm{Pb}$

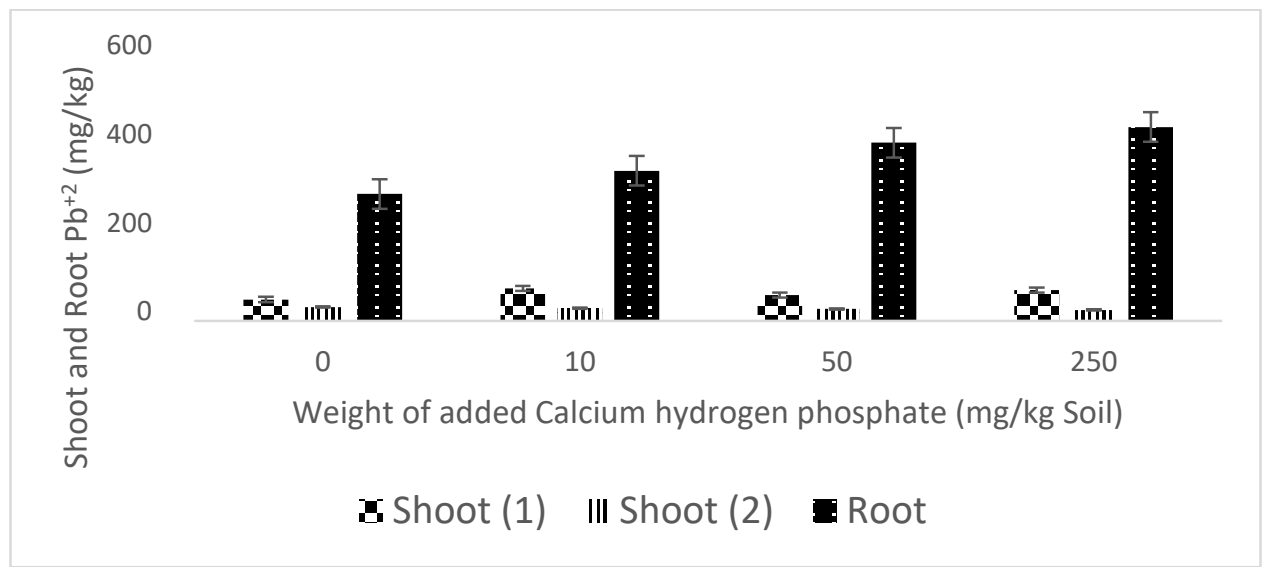

Figure 6: Changes in shoot and root lead concentrations against weight of added calcium hydrogen phosphate at $1000 \mathrm{mg} \mathrm{Pb}^{+2}$

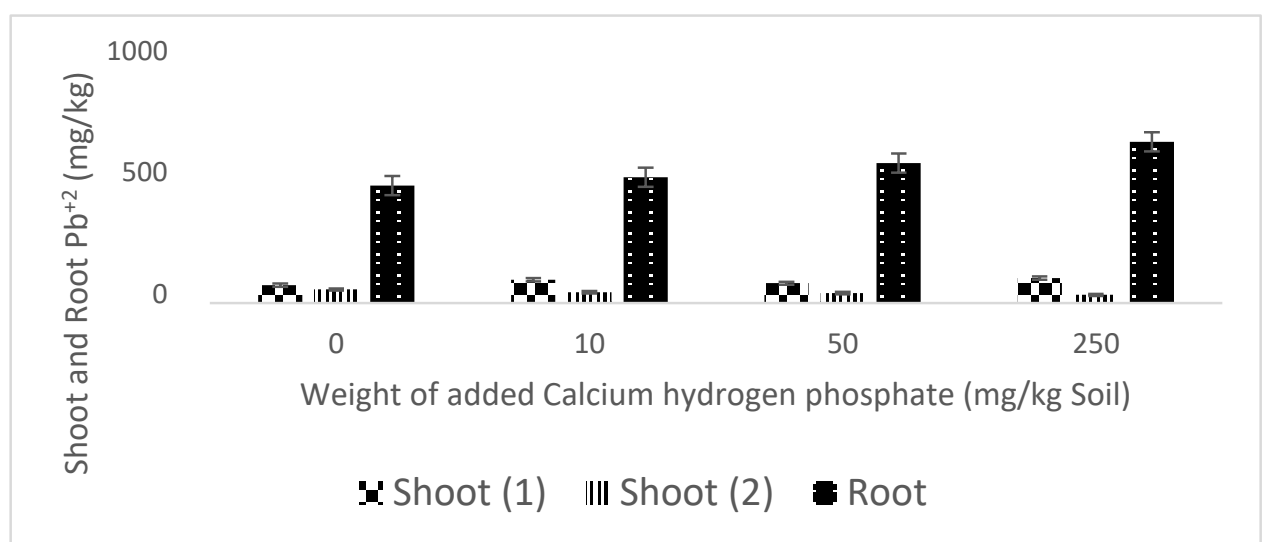

Figure 7: Changes in shoot and root lead concentrations against weight of added calcium hydrogen phosphate at $3000 \mathrm{mg} \mathrm{Pb}^{+2}$

From the first harvest as shown in Figures 5, 6 and 70, the shoot lead concentration in lead control soil was $8.9760 \pm 1.7190 \mathrm{mg} / \mathrm{kg}$ compared with $48.4595 \pm 5.1124$ and $74.6107 \pm 4.5802 \mathrm{mg} / \mathrm{kg}$ in soils amended with lead at 1000 and $3000 \mathrm{mg} / \mathrm{kg}$ respectively. Root lead concentration increased from $92.5183 \pm 4.3547 \mathrm{mg} / \mathrm{kg}$ in lead control soil to $437.0264 \pm 15.8298$ and $665.2758 \pm 26.3897 \mathrm{mg} / \mathrm{kg}$ in soils amended with 1000 and $3000 \mathrm{mg} / \mathrm{kg} \mathrm{Pb} \mathrm{Pb}^{+2}$ and $250 \mathrm{mg} / \mathrm{kg}$ phosphate respectively. Root lead concentrations therefore were clearly much greater than shoot concentrations.

Phosphate addition to soil had no influence over shoot lead concentrations in the first and second harvests in lead control soil. In soil amended with $1000 \mathrm{mg} / \mathrm{kg} \mathrm{Pb}^{+2}$ (Figure 6), addition of $50 \mathrm{mg} / \mathrm{kg}$ phosphate significantly lowered shoot lead 
concentration in the second harvest from $31.3257 \pm 2.5056$ to $26.9898 \pm 4.9509 \mathrm{mg} / \mathrm{kg}(\mathrm{P}<0.05)$. With $250 \mathrm{mg} / \mathrm{kg}$ phosphate addition, the shoot lead concentration was further reduced to $24.9530 \pm 6.4124 \mathrm{mg} / \mathrm{kg}$. Although root lead concentrations demonstrated an increasing trend with increased phosphate addition, no statistically significant effect of phosphate was observed.

\section{Total Phosphate in Shoots and Roots}

Figures 8 to 10 show the changes in shoot and root total phosphate against weight of added calcium hydrogen phosphate.

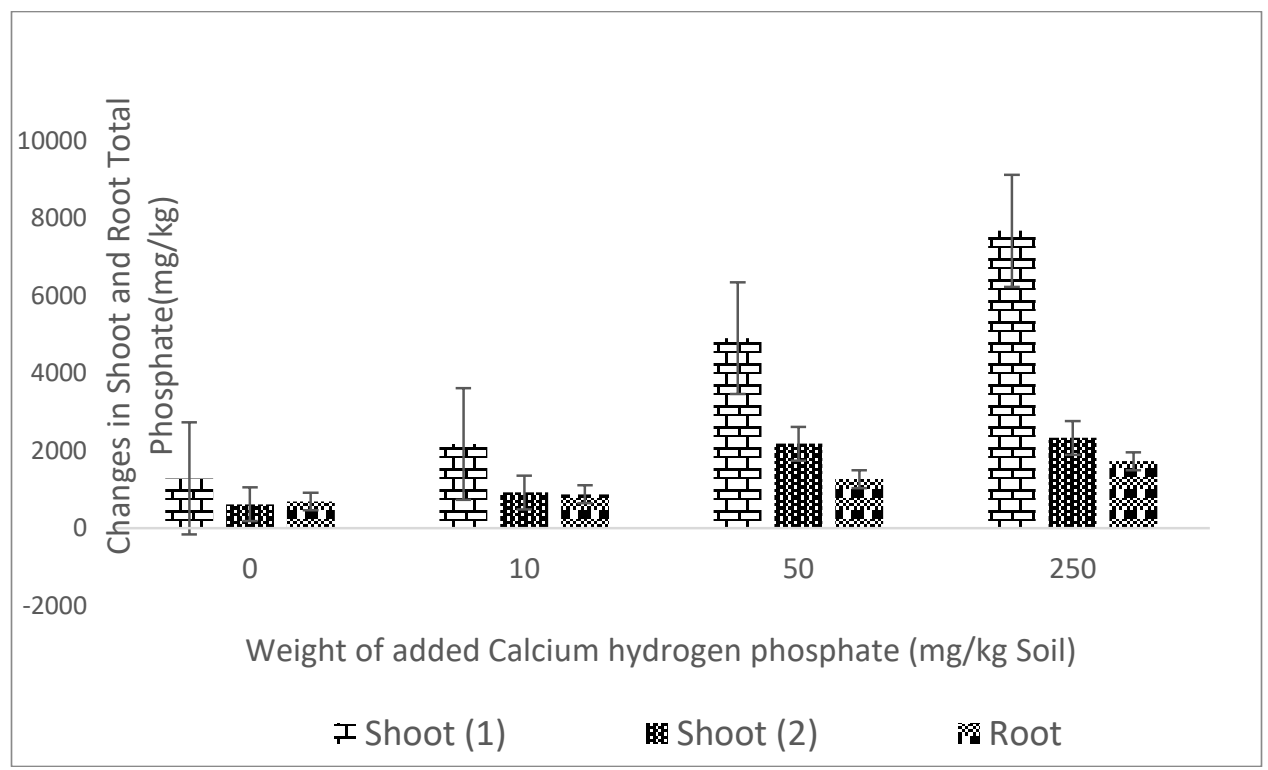

Figure 8: Changes in shoot and root total phosphate against weight of added calcium hydrogen phosphate at $0 \mathrm{mg} \mathrm{Pb}$

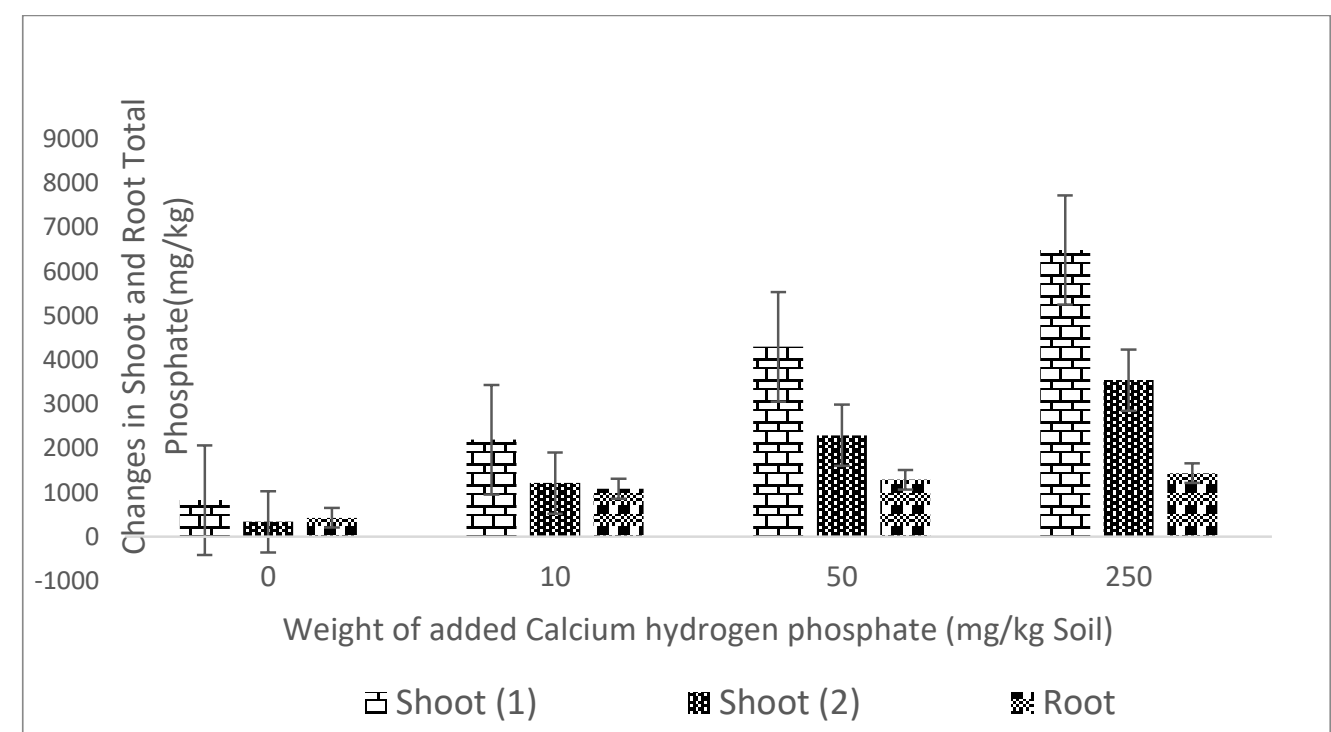

Figure 9: Changes in shoot and root total phosphate against weight of added calcium hydrogen phosphate at $1000 \mathrm{mg} \mathrm{Pb}^{+2}$ 


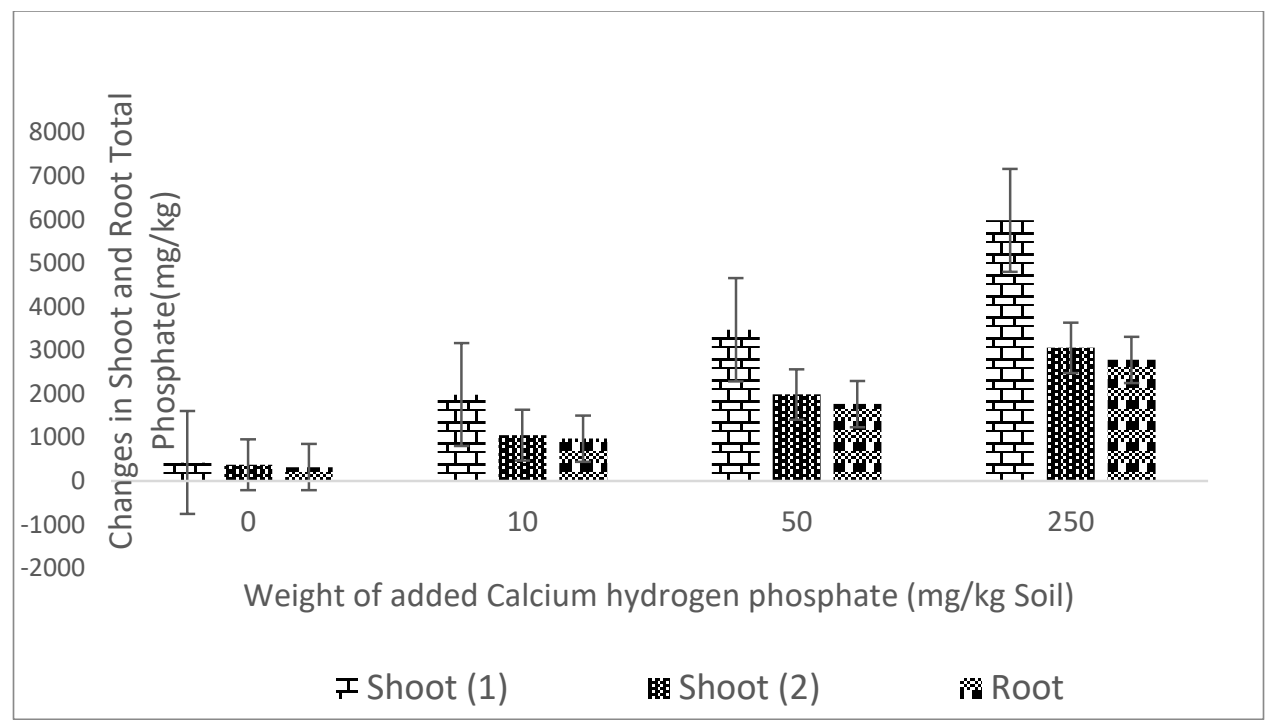

Figure 10: Changes in shoot and root total phosphate against weight of added calcium hydrogen phosphate at $3000 \mathrm{mg} \mathrm{Pb}^{+2}$

Addition of lead to soil did not significantly affect shoot phosphate concentrations in the first or second harvest, nor did it affect root phosphate concentrations. Phosphate additions however raised shoot phosphate concentrations (both harvests) and root phosphate concentrations $(\mathrm{P}<0.001)$. In each instance addition of $250 \mathrm{mg} / \mathrm{kg}$ phosphate resulted in the maximum increase in phosphate concentration (Figures 8,9 and 10). Considering the second harvest, shoot phosphate concentrations in lead control soil increased from $618.2317 \pm 28.4316 \mathrm{mg} / \mathrm{kg}$ to a maximum of $2335.4851 \pm 59.6481 \mathrm{mg} / \mathrm{kg}$ when $250 \mathrm{mg} / \mathrm{kg}$ phosphate was added to the soil (Figure 8). In soil amended with $1000 \mathrm{mg} / \mathrm{kg}$ $\mathrm{Pb}^{+2}$ however, shoot phosphate concentrations increased from $338.6138 \pm 23.6812 \mathrm{mg} / \mathrm{kg}$ in unfertilized soil to $3543.2273 \pm 47.2614 \mathrm{mg} / \mathrm{kg}$ where $250 \mathrm{mg} / \mathrm{kg}$ phosphate was added to soil (Figure 9).

Many authors including Seregin et al. (2004), Sharma \& Dubey, (2005), Kopittke et al. (2007), Meyers et al. (2008) have demonstrated decreased yield in metal contaminated soil similar to results observed in this study. Heavy metals have been shown to be toxic to plant biochemical pathways and hence to growth if present in sufficient concentration. Liu et al. (2008), Qufei and Fashui (2009) demonstrated inhibition of photosynthesis by elevated lead concentrations. Steps in the formation of reactive oxygen Romanowska et al. (2008), Sengar et al. (2009) and Bhattacharjee (2005) will interfere with plant function, thus decreasing either production of carbohydrate, or the rate at which this is metabolised, so resulting in decreased growth. Addition of $3000 \mathrm{mg} / \mathrm{kg} \mathrm{Pb}$ to soil is a relatively high level of contamination and could bring about such effects.

Shoot yield in the first harvest was increased by the addition of $250 \mathrm{mg} / \mathrm{kg}$ phosphate to soil which suggests that the available phosphate concentration in control soils was less than optimal for growth. It is likely that added lead will complex with available phosphate in soil to produce an insoluble compound which is not taken up by plant roots and this could reduce phosphate availability. This may further decrease yield that is already low due to the naturally sub-optimal conditions. Where soils were fertilized with phosphate, any effect of lead addition was largely removed. This suggests that addition of phosphate reduced lead uptake to a level where physiological functions were not impaired to an extent which decreased yield. It also indicated amelioration in the physiological dysfunction caused by lead as demonstrated by Macpherson and Martin (1994).

Although there was a strong increasing trend with increasing phosphate addition, no significant difference in root lead concentration or total root lead levels was found between soil phosphate treatments. Despite root yield increasing with addition of phosphate to lead amended soil, no greater uptake of lead was observed to coincide with this greater utilization of soil. The root mass was so great in most of the soil treatments that the greater portion of soil was probably being utilized by the plant anyway. With comparable soil lead concentrations between phosphate treatments, any differences in shoot lead concentration may arise either through growth dilution or through precipitation of lead on roots due to the presence of increased concentrations of phosphate.

Results obtained in this study are in consonance with the report of Macpherson and Martin (1994). They observed that large lead and phosphate deposits in dictyosomes of plant roots were transported through the cytoplasm where they became fused with the cell wall thus removing soluble lead from sites of biochemical importance to relatively stable or inactive stores. This suggests that root phosphate status had no influence on lead translocation to shoots.

\section{CONCLUSION}

Increases in shoot yield brought about by phosphate fertilization decreased the shoot lead concentration. The increase in dry weights ranged from $11.0353 \pm 0.3405$ to $16.1208 \pm 2.9486 \mathrm{mg} / \mathrm{kg}$ for first shoot harvest, $10.8052 \pm 0.6701$ to $14.6984 \pm 0.5751 \mathrm{mg} / \mathrm{kg}$ for second shoot harvest and $27.3279 \pm 1.5730$ to $33.7873 \pm 0.0832$ for roots. In all instances, $10 \mathrm{mg} / \mathrm{kg}$ of calcium hydrogen phosphate was sufficient to bring about the increase in yields. The total amount of lead in shoots was unaffected by phosphate treatment. No evidence was found to suggest a phosphate mediated reduction in lead availability in soil, or decreased translocation in plants. 


\section{ACKNOWLEDGEMENTS}

Our thanks go to Mal. Mustapha M. Uba and Mal. Yakubu S. Shitu of the Department of Soil Science, Bayero University, Kano, Mal. Abdullahi Haruna of International Institute of Tropical Agriculture (IITA), Kano for their invaluable contributions to the success of this work.

\section{REFERENCES}

.Allen, S. E. (1989). Chemical Analvsis of Ecological Materials. (2nd Ed.) Blackwell Scientific Publications, Edinburgh, London.

Bhattacharjee, S. (2005). Reactive oxygen species and oxidative burst: roles in stress, senescence and signal transduction in plants. Curr. Sci., 89(7): 1113-1121

Kabata-Pendias, A. and Pendias, H. (2001). Trace Elements in Soils and Plants. 3rd ed. CRC, Boca Raton Press, p413

Dagari, M. S., Jimoh, W. L. O. and Musa, M. S. (2020). Effects of EDTA on Extraction of added Lead in Soil and its Uptake by Cowpea. Chemsearch Journal, 11(1): In Press.

Kopittke, P. M., Asher, C. J., Kopittke, R. A. and Menzies, N. W. (2007). Toxic effects of $\mathrm{Pb}^{2+}$ on growth of cowpea (Vigna unguiculata). Environ Pollut., 150(2): 280-287

Liu, D., Li, T., Jin, X., Yang, X., Islam, E. and Mahmood, Q. (2008). Lead induced changes in the growth and antioxidant metabolism of the lead accumulating and non-accumulating ecotypes of Sedumalfredii. J Integr. Plant Biol., 50(2): 129-140

Macpherson, S. A. and Martin, M. H. (1994). Effects of Phosphate Additions to Soil on Lead and Phosphate Concentrations of Holcus Lanatus Grown on Lead Amended Soil, Chemosphere, 29(12): 2571-2581

Meyers, DER., Auchterlonie, G. J., Webb, R. I. and Wood, B. (2008). Uptake and localisation of lead in the root system of Brassica juncea, Environ. Pollut., 153(2): 323-332
Mishra, S., Srivastava, S., Tripathi, R. D., Kumar, R., Seth, C. S. and Gupta, D. K. (2006). Lead Detoxification by Coontail (Ceratophyllum demersum L.) involves Induction of Phytochelatins and Antioxidant System in Response to its Accumulation. Chemosphere, 65(6): 1027-1039

Qufei, L. and Fashui, H. (2009). Effects of $\mathrm{Pb} 2+$ on the Structure and Function of Photosystem II of Spirodela polyrrhiza, Biol. Trace Elem. Res., 129(1): 251-260

Romanowska, E., Wróblewska, B., Dro-zak, A., Zienkiewicz, M. and Siedlecka, M. (2008). Effect of Pb ions on superoxide dismutase and catalase activities in leaves of pea plants grown in high and low irradiance, Biol. Plantarum., 52(1): 80-86

SAS (Statistics for Applied Sciences) (2002). SAS/STAT User's Guide, Version 6, $5^{\text {th }}$ Edition, Inc. Cary NC, USA, Pp 6-8.

Sengar, R. S., Gautam, M., Sengar, R. S., Sengar, R. S., Garg, S. K., Sengar, K. and Chaudhary, R. (2009). Lead stress effects on physiobiochemical activities of higher plants. Rev. Environ. Contam. Toxicol., 196: 1-21

Seregin, I. V. and Ivanov, V. B. (2001). Physiological Aspects of Cadmium and Lead Toxic Effects on Higher Plants, Russ. J. Plant Physiol., 48(4): 523-544.

Seregin, I.V., Shpigun, L. K. and Ivanov, V. B. (2004). Distribution and toxic effects of cadmium and lead on maize roots. Russ. J. Plant Physiol., 51(4): 525-533

Sharma, P. and Dubey, R. S. (2005). Lead toxicity in plants. Braz. J. Plant Physiol., 17(1): 35-52

Wong, M. H. and Lau W. M. (1985). The effects of Applications of Phosphate, Lime, EDTA, Refuse Compost and Pig Manure on Pb Contents of Crops. Agricultural Wastes, 12: $61-75$

Wuana, R. A. and Okieimen, F. E. (2011). Heavy metals in contaminated soils: A Review of Sources, Chemistry, Risks and Best Available Strategies for Remediation. Int. Scholarly Res. Network Ecol., 1-20. 